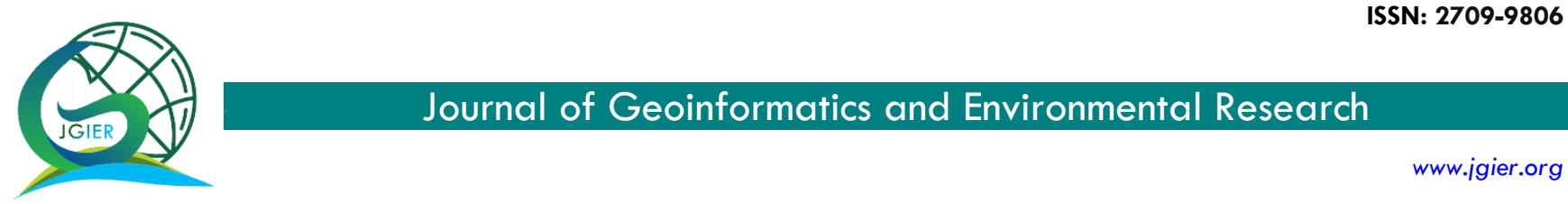

\title{
Mapping Ecosystem Service: Challenges and Solutions
}

\author{
Mosa Asaad Ibrahim ${ }^{1 *}$, Hazhir Karimi², Yaseen Taha Mustafa², Mohammad Khalid Hassan ${ }^{1}$ \\ ${ }^{I}$ Forestry Department, College of Agricultural Engineering Science, University of Duhok, Duhok, Kurdistan Region-Iraq, \\ (mosa.ibrahim,mhassan)@uod.ac \\ ${ }^{2}$ Deptarment of Environmenal Science, Faculty of Science, Univerasity of Zakho, Duhok, Kurdistan Region-Iraq (hazhir.karimi, \\ yaseen.mustafa)@uoz.edu.krd \\ *Correspondence: mosa.ibrahim@uod.ac
}

\begin{abstract}
The concept of ecosystem service (ES) was originally developed to illustrate the benefits that natural ecosystems generate for society and to raise awareness for biodiversity and ecosystem conservation. In recent years, geographical information system (GIS) has become a powerful tool for mapping (ES) within a landscape, which visualizes spatial and temporal patterns and changes in ecosystems and their services.Mapping (ES) is necessary for the progress of strategies that will guarantee their future supply and to support the policies in a more effective way. The comprehensive literature review were conducted from international databases such as Elsevier, Springer, Wiley, and Google Scholar. We used the key terms including 'mapping', 'maps', 'ES or ecosystem service, 'ecosystem functions', 'landscape functions', 'evaluation of ES', and 'assessment of services'. in order to identify mapping ecosystem services and their challenges and opportunities. In total, 65 research papers were found firstly, which 34 of them were selected for reviewing. The most mportant challenges are insuffieicnet generation of $\mathrm{ES}$ in the context of managed systems, need to estimate associations among indicators of (ES) incomplete understanding of the nature of associations among services, and the lack of a general numerical outline to address these relations.
\end{abstract}

Keywords: Ecosystem Services, Human Welfare, GIS, Mapping

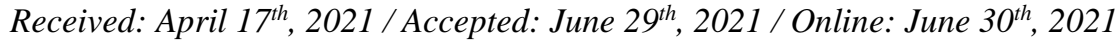

\section{Introduction}

Ecosystem services (ES) are the assistances of ecosystem function and structure (in mixture with other inputs) to human welfare. This indicates that mankind is powerfully based on well-functioning ecosystems and natural resources that are the foundation for a continuous flow of ES from nature to humanity.

The concept of (ES) has evolved with a focus on both at the degree of economic significance, where ES is the profits humans derive, indirectly or directly, from ecosystem purposes or the ecological basis as ES being the methods and conditions through which natural ecosystems and their classes sustain and achieve human life. Despite these variances, all definitions stress the association among human security and (natural) ecosystems and the services are the 'bridge' between the natural world and the social world, with only humans being practically divided from that natural world (Balzan, Potschin-Young, and Haines-Young 2018). 
The human being benefits from the ecosystems, such as food, clean air, fresh water, flood and illness control, and the pollination of yields, as well as chances for spiritual, cultural and recreational skills. Human welfare and survival is completely based on these ecosystem services, and hence on the health of the ecosystems that offer them (Costanza et al. 2014).

The Millennium Ecosystem Assessment (MA) distributes ES into four services: (1) provisioning services: goods resulting from ecosystems (e.g., freshwater, livestock, seafood); (2) supporting services: facilities that are essential for the manufacture of other ecosystem purposes (e.g. conservation of habitat or biodiversity for species); (3) cultural services: non-material services (e.g. recreation and tourism and aesthetic values), and (4) regulating services: benefits obtained from the regulation of ecosystems (e.g. climate regulation, air quality, water purification and natural hazard protection) (Mooney 2005).

Ecosystem services mapping is important to know how ecosystems relate to human welfare and to support strategies and policies which influence natural capitals. Maps can professionally link complex spatial data and people commonly desire to look at maps and to search their practical and content applicability. Spatially explicit valuation is required to better recognize and measure the demand and supply of ecosystem services to help decision-making and communication, and to fulfil importance on the governmental program to guarantee future supply (Crossman et al. 2013).

Consequently, ES maps are very valuable for raising consciousness on the zones of ecosystem facilities and goods demand and supply, environmental study about human-based on operational nature and preparing material about interregional ecosystem services and goods streams (Gurnell 2016). Moreover, maps are required tools for landscape arrangement, environmental reserve management and (spatial) land use optimization. Natural protection, environmental conservation and rebuilding to achieve the necessities of the above-mentioned applications, great quality, robust and reliable data and data on ES supply, demand and stream are required at various temporal degrees and spatial.

In this paper, we reviewed the published papers of mapping ecosystem services challenges from international databases. Most of the considered papers for this review paper were presented in Table 1. In particular, we aim to (1) what type of ES were mainly mapped, (2) identify the types of sources of information that were used to map ES, and the spatial and temporal scales for ES mapped, and (3) classify the types of methods used to model and map ES, (4) tools and types of methodological to using PPGIS/PGIS for mapping ecosystem services, and (5) identify mapping ecosystem services challenges and solution by using GIS.

Table 1: The most commen research papers of mapping ecosystem services

\begin{tabular}{|c|c|c|c|}
\hline No. & Author(s) & Study & Journal \\
\hline 1 & $\begin{array}{l}\text { Jax, K., Furman, E., Saarikoski, } \\
\text { H., Barton, D. N., Delbaere, B., } \\
\text { Dick, J., ... \& Watt, A. D. (2018) }\end{array}$ & $\begin{array}{l}\text { Lessons learned when trying to make the ecosystem services } \\
\text { concept operational. Ecosystem services }\end{array}$ & $\begin{array}{l}\text { Elsevier- Ecosystem } \\
\text { services, 29, 415- } \\
427 .\end{array}$ \\
\hline 2 & Burkhard, B., \& Maes, J. (2017). & Mapping ecosystem services. & $\begin{array}{l}\text { Advanced books, } 1 \\
\text { e12837. }\end{array}$ \\
\hline 3 & $\begin{array}{l}\text { Yeakley, J. A., Ervin, D., } \\
\text { Chang, H., Granek, E. F., Dujon, } \\
\text { V., Shandas, V., \& Brown, D. } \\
(2016) .\end{array}$ & $\begin{array}{l}\text { Ecosystem services of streams and rivers. River science: } \\
\text { research and management for the } 21 \text { st century. }\end{array}$ & $\begin{array}{l}\text { Wiley-Blackwell, } \\
\text { Chichester, 335- } \\
352 .\end{array}$ \\
\hline 4 & $\begin{array}{l}\text { Haase, P., Tonkin, J. D., Stoll, } \\
\text { S., Burkhard, B., Frenzel, M., } \\
\text { Geijzendorffer, I. R., ... \& } \\
\text { Schmeller, D. S. (2018). }\end{array}$ & $\begin{array}{l}\text { The next generation of site-based long-term ecological } \\
\text { monitoring: Linking essential biodiversity variables and } \\
\text { ecosystem integrity. }\end{array}$ & $\begin{array}{l}\text { Science of the Total } \\
\text { Environment, } 613 \\
1376-1384 .\end{array}$ \\
\hline
\end{tabular}


Gomes, E., Inácio, M.,

5 Bogdzevič, K., Kalinauskas, M., Karnauskaitè, D., \& Pereira, P. (2021).

da Silva, C. V., Ortigão, M.,

6 Willaert, T., Rosa, R., Nunes, L. C., \& Cunha-e-Sá, M. A. (2021).

Nemec \& Raudsepp-Hearne, 2013

Egoh et al., 2012

Bicking, S., Burkhard, B., Kruse, M., \& Müller, F. (2018)

Scholte, S. S., Daams, M.,

10 Farjon, H., Sijtsma, F. J., van Teeffelen, A. J., \& Verburg, P. H. (2018).

Maes, J., Burkhard, B., \& Geneletti, D. (2018).

Kobryn, H. T., Brown, G., 12 Munro, J., \& Moore, S. A. (2018).

$13 \quad$ Villa et al. 2014

$14 \quad$ Bagstad et al.2013

15 Guerry et al., (2012)

Kareiva et al. 2011

17 Crossman et al., 2013;

18 (Grêt-Regamey et al., 2014
Future scenarios impact on land use change and habitat quality in Lithuania.

Participatory Geographic Information Systems (PGIS): Alternative approaches to identify potential conflicts and positional accuracy in marine and coastal ecosystem services.

The use of geographic information systems to map and assess ecosystem services

Mapping ecosystem services for policy support and decision making in the European Union

Mapping of nutrient regulating ecosystem service supply and demand on different scales in Schleswig-Holstein, Germany.

Mapping recreation as an ecosystem service: Considering scale, interregional differences and the influence of physical attributes.

Ecosystem services are inclusive and deliver multiple values. A comment on the concept of nature's contributions to people.

Cultural ecosystem values of the Kimberley coastline: An empirical analysis with implications for coastal and marine policy.

From theoretical to actual ecosystem services: mapping beneficiaries and spatial flows in ecosystem service assessments

A comparative assessment of decision-support tools for ecosystem services quantification and valuation

Modeling benefits from nature: using ecosystem services to inform coastal and marine spatial planning

Conservation science. balancing the needs of people and nature.

A blueprint for mapping and modelling ecosystem services

Mapping and Assessment of Ecosystems and their Services: Indicators for ecosystem assessments under Action 5 of the EU Biodiversity Strategy to 2020
Environmental Research, 197, 111101.

Marine Policy, 131, 104650

Springer link.

Biodiversity and conservation, 22(1), 1-15.

Elsevier- Ecosystem services, 1(1), 31-

39.

One Ecosystem 3 (2018).

Landscape and

Urban

Planning, 175, 149-

160.

One Ecosystem 3 (2018).

Ocean \& coastal management, 162 , 71-84.

JSTOR. Ecology and Society, 19(2).

Science direct.

Ecosystem services, 5, 27-39.

International

Journal of

Biodiversity

Science, Ecosystem

Services \&

Management

Greenwood

Village, Colorado.

Roberts and

Company. c2011

Science direct

University of

Twente 
Hein et al., 2006

20

Costanza et al., (1997)

21
Tallis\& Polasky 2009; Nelson et al., 2009
Spatial scales, stakeholders and the valuation of ecosystem services

Changes in the global value of ecosystem services

Modeling multiple ecosystem services, biodiversity conservation, commodity production, and tradeoffs at landscape scales
Elsevier.

Ecological

economics, 57(2), 209-228.

Elsevier. Global environmental change, 26, 152158.

ESA. Frontiers in Ecology and the Environment, 7(1), 4-11.

\section{Mapping Ecosystem Services}

\subsection{Why is Mapping Ecosystem Services Important?}

Mapping ES permits a user to visualize information, assisting to find spatial patterns, gaps, and intersections that are then problematic to conceptualize. In addition, it:

1. Allow operators to discover changes with time, build scenarios and observe potential future influences of control, which are particularly significant when working across zones.

2. Allow operators to do explore and spatial analysis of the relations among different landscape/seascape characters and their drivers of change.

3. Provides a background to help support decision-making and dialogue (Maes et al. 2015).

4. Permits users to compare datasets, recognize synergies, information gaps or struggles, highlighting what and where information must be collected.

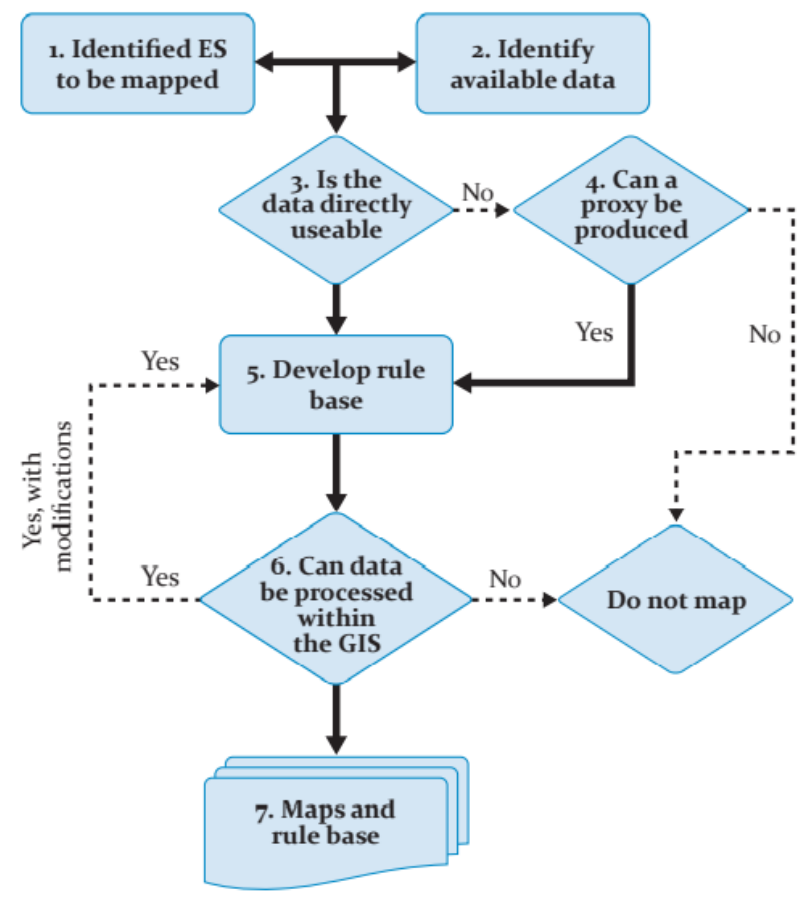

Figure 1. Decision tree on ecosystem services mapping (Burgess et al. 2016). 


\subsection{Mapping Outlines for Ecosystem Services}

The UK government Joint Nature Conservation Committee has established a valuable methodological spatial framework that performance as a thorough decision tree on mapping ES (Figure 1).

Overall, most frameworks for mapping ES trust upon a stacked method in a GIS system, as outlined below (Figure 2). The combination among layers is frequently not easy as the data comes in various resolutions and units and some standardization is generally necessary for all the information to be stacked in the way explained. The stacked mapping method also outlines increasing complexity, from simple data presentation to the natural resources, through a valuation of production of the flows, service, beneficiaries, welfares and expenditures. For full mapping research, based on the exact mapping purpose, all these components should be involved, but in most research, only the first few components are mapped.

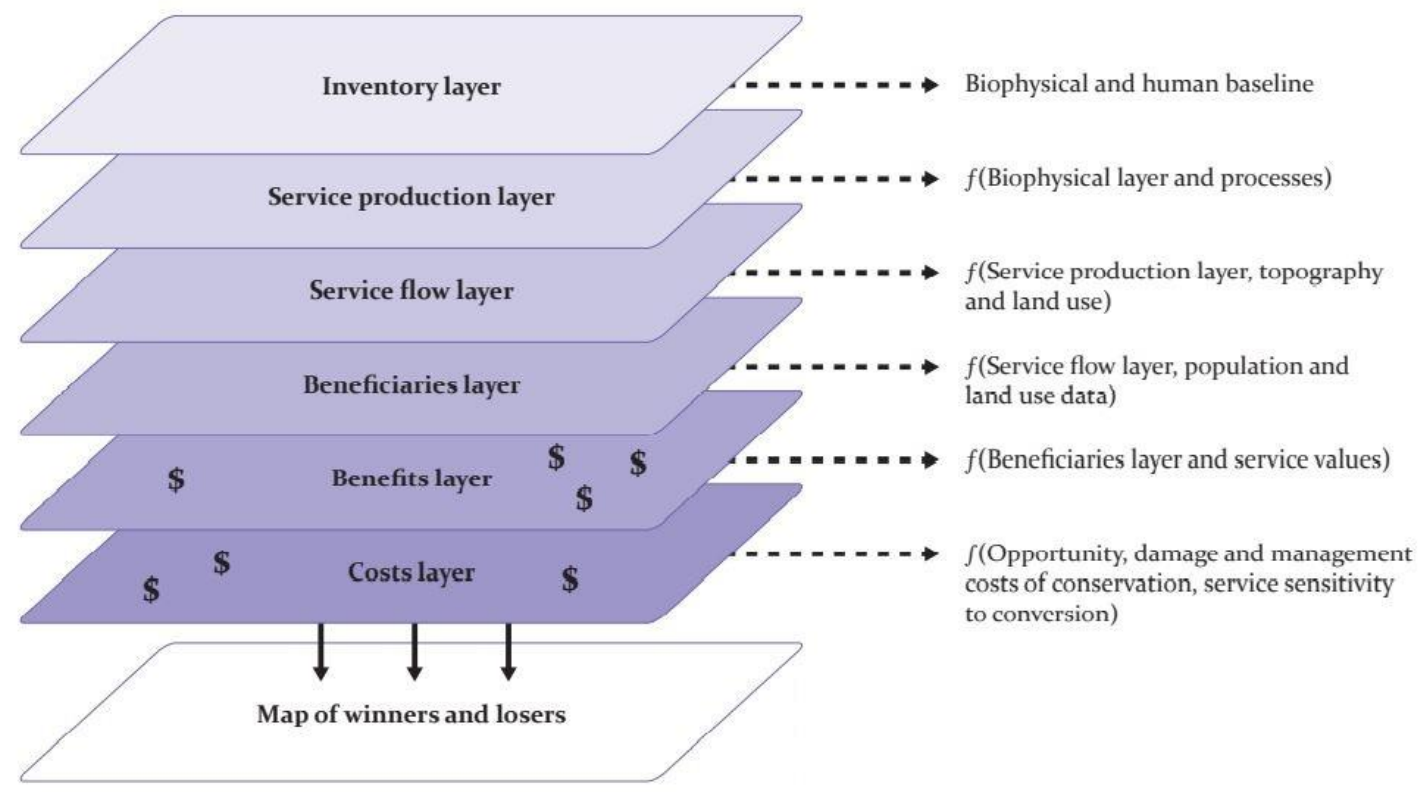

Figure 2. framework used to map ecosystem services using a series of overlaid GIS layers (Swetnam et al. 2011).

\subsection{Practical Choices to be Made Before Mapping}

\subsubsection{Purpose}

The most essential consideration of any ES mapping implementation is 'The reason is this being done?' and 'for who is this being done?' and very frequently 'what do we need to see change as a result of doing this?') (Crossman et al. 2013). Identify the goals is critical and must be determined before taken of the points below.

\subsubsection{Spatial Scale}

The geographical level (area) of the ES mapping application can differ from a small location at the local scale, to state, regional, continental and even universal extents. The supply, consumption and reserve management of ES work at local scales, whereas values, benefits, and demand drive across all scales (Roche 2014).

\subsubsection{Resolution of analytical units}

The main aiming of GIS analysis is to map ES, grid cells of various sizes are frequently applied to support the information processing. Raster grid cells can be applied for decision-making if they are of a suitable resolution to be used on the earth. Though, if the grids are much bigger than the ruler of making the decision then they will be of slight practical usage. On the other hand, real-world limitations such as property limits, which derive in the form of polygons, can analyze ES hard to run and it can scale decision be difficult to compare ES values 
among properties of various sizes. Furthermore, the utility of the method for finer -making will reduces once ES values are generalized within polygons (Burgess et al. 2016).

\subsubsection{Temporal Scale}

The opportunity of temporal degree will have based on the intended outcome of the map and of the causal process of conversion in the ES of attention (Cash et al. 2006). Daily, monthly, quarterly, annual and decadal levels can be measured; the most valuable scale for one service will not be similar for the next. Temporal matters also include the time passing among ES generation and the final practice by the recipient.

\subsection{Input data}

Input data are mostly divided into four different classes for ES mapping studies: biophysical, national statistics and social information collecting in the field, remote sensing (Mzuri et al., 2021) and outputs of statistical simulation modelling (Crossman et al. 2013).

\subsubsection{National / Regional statistics}

Essential input data for many types of ES mapping workouts span the fields of ecological (e.g. forest type), social (human population density), biophysical (topography) economic benefit (natural timber) and Most of this information are collected regularly by different state and universal processes and are frequently found in national numerical offices (Burgess et al. 2016).

\subsubsection{Field assessments}

Data collecting in the field can be carried out by trained scientists, community observing schemes and focus group debates (Mascia et al. 2014), questionnaires-surveys for populations and hand-held electronic instruments are also beneficial means for information gathering in the ground (Lwin and Murayama 2011). Field information can be fed straight into ES maps or applied as a technique to legalize and parameterize models resulting from remotely sensed information products. There are several challenges with gathering main data; particularly because it is time-consuming, costly and requires technical skill.

\subsubsection{Remote sensing}

Remote sensing involves data gathering 'at a distance' from aircrafts, or computerized sensors on the earth, in water, or from space (Hoffmann et al. 2014). Remote sensing can be applied to predicate both ocean and terrestrial initial production which means that production of yields, wood, feed, and biofuel, and regulation of climate through variations in carbon stock can be calculated (Al-Quraishi et al. 2022, Hassanpour \& YT Mustafa 2018, Obeyed et al. 2018).

\subsection{Ecosystem Services Mapping Methods}

\subsubsection{Proxies and indicators}

Generally, this method has been applied for mapping natural resources and ES (Nemec and Raudsepp-Hearne 2013). The indicator and proxy method is most generally applying for regulating, cultural and supporting services (Forrest 1980). For instance, agricultural terrestrial is frequently used as a proxy for food manufacture.

\subsubsection{Modelling}

The open-source modelling outline named Artificial Intelligence for ES (ARIES) includes artificial intelligence (AI), mechanism reasoning and pattern recognition in mixture with an ES spatial information and library (Bagstad et al. 2014). ARIES have in its functionalities probabilistic models for water supply, carbon confiscation and sight shed analysis (Bagstad et al. 2013).

InVEST is an instance of a complex model-based GIS device that utilizes ecological production functions to map ES across the landscape and can convert these according to various scenarios. (Nemec and RaudseppHearne 2013) used this modelling method to ES map in marine and coastal environments. For the cultural service 'recreation' they applied to fish and whale abundance and beach situations as supply indicators, the 
number of sightings, catch rates and visitation rates as service indicators and net revenue as a beneficial indicator. The associations among the service and supply are modelled and mapped across the zone (Guerry et al. 2012).

Reasons for the implementation of modelling methods in Ecosystem Services. The service is being measured using different of statistical data bases as inputs e.g. extreme event regulation utilize inputs such as temperature, slope and soil organic component.

Limited ground information is being extrapolated to the regional ruler, e.g. charcoal production in Tanzania (Schaafsma et al. 2012). Theoretical scenarios and influences are being explored e.g. the effects of different land management policies. The service cannot be directly calculated e.g. climate regulation.

\subsubsection{Participatory GIS (PGIS)}

GIS can be applied to visualize how ecosystem services are scattered across a landscape, to compare the scatterings of many ecosystem services with drivers of change and other social-ecological limitations, and to model how changes in land protection or land usage, land management, ecosystem and climatic situations, and human populations impact ecosystem service provision and use of services and the value(Nemec and Raudsepp-Hearne 2013).

The PPGIS/PGIS is very important because is supported by the theory of crowd wisdom wherein combined intelligence can be harnessed to find superior solutions to challenging community problems(Nemec and Raudsepp-Hearne 2013). Identify ecosystem services may also be harnessed by crowd wisdom.

The ecosystem services mapping implement PPGIS/PGIS is intended to offer a more inclusive valuation of ecosystem services where trade-offs can be observed, causal to current efforts to develop mapping ecosystem service (Crossman et al. 2013). Though, to date, there has been no methodical review to estimate PPGIS/PGIS approaches to determine their comparative limitations and strengths in evaluating and analyzing ecosystem services.

The technology applied to ecosystem services mapping has included two main types: (2) digital mapping on a laptop, particularly using internet map services such as those provided by Googles and (1) hardcopy topographical-cartographical maps or aerial image maps joint with a marking system such as pen, pencil, beads, stickers, cubes, or discs.

\subsection{Mapping at Different Scales}

Estimating of maps of ecosystem services vary significantly at various resolutions and the various methods of mapping makes comparability of ES analyses hard (Rabe et al. 2018). At regional and universal scales, data repeatedly involve remotely sensed or combined country-level data. This information is frequently at coarseresolutions which limits the applicability of model effects on the earth, though, at this ruler dataset are often more comparable. Models Appling national-level data e.g. national data and databases and expert proof workshops are often more relevant for application on the earth, such data can also be improved by global datasets. (Bicking et al. 2018).

At the regional scale, models are mostly depending on data gathered from examination, experts and various user groups, this fine resolution information is the most practical and valuable to act on the ground but it is hard to generalize the outcomes of these models to global and local scales. Deciding the suitable scale of ES mapping needs an understanding of how the maps will be applied, the interest of decision makers in the production, how the variables under consideration impact ES interactions and so on (Scholte et al. 2018).

\subsection{Mapping Values}

The value of ES will be obtained by the participants who profit, indirectly or directly, from the ecosystem services (Burgess et al. 2016). The general value of ecosystems is naturally divided into non-use and use values 
that are, in turn, disaggregated into various value elements. The Total Economic Valuation (TEV) outline is a well-known typology for categorizing these different elements (Burgess et al. 2016).

There are different methods to measure the value of an ES, the suitability of which is based on the value kind in query, data existing and capacity to undertake the analysis. These can be approximately classified as marketbased, revealed preference and stated preference approaches. Under these methods values are normally estimated on the combined value of all relevant services provided by various ecosystems on a per-area basis apply the TEV or similar frameworks.

The first attempt of (Costanza et al. 2014) was the value transfer method to estimate and map the value of ES in economic terms at a universal scale, which was updated in 2014 others have applied for the value transfer in order to measure and map the economic value of ES at local or global scales (Maes, Burkhard, and Geneletti 2018).

\subsection{Mapping Tools}

The ES mapping tools were divided into several groups based on the usability (Table 2):

1. Independently applicable, place-specific, landscape-scale modelling instrument: Envision, EPM, in forest.

2. Independently appropriate, generalizable, landscape-scale modeling instrument: ARIES, Costing Nature, EcoServ, InVEST, Water World, Wildlife Trade Mapper, Universal Forest Water Climate tool, MIMES, LUCI, SolVES.

3. Regional-scale modelling tools: LUCI, EcoMetrix

4. Proprietary, generalizable, landscape-scale modelling tools: ESValue, EcoAIM

5. Economic valuation tools: Benefit Transfer and use Valuing Model toolkit, Ecosystem Estimation Toolkit, NAIS

The Integrated Valuation of Ecosystem Services and Tradeoffs tool (InVEST) advanced by the Natural Resources Project has already been explained in published studies (Nelson et al. 2009). So far, this tool, which purposes at associating models of ecological production functions with economic valuation approaches, includes a limited quantity of ES as well as terrestrial biodiversity.

Table 1. Different ecosystem service mapping and decision support tools and their usability (Burgess et al. 2016).

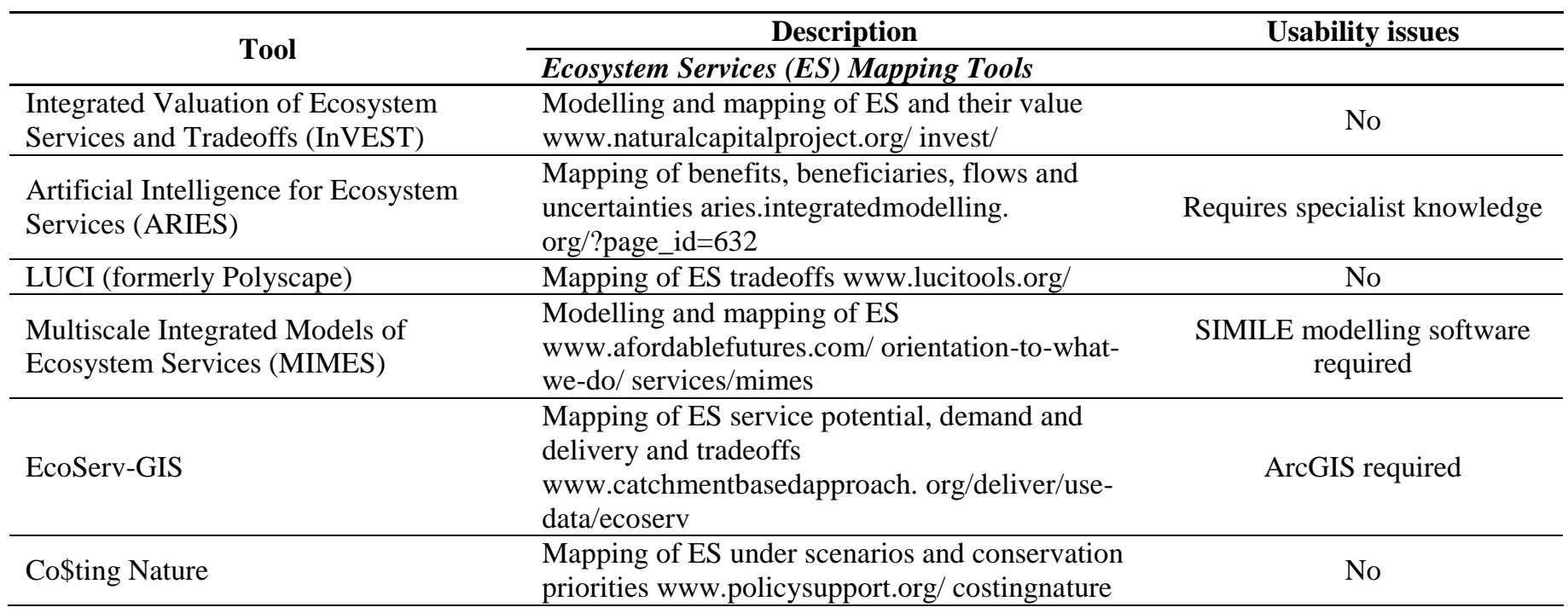




\begin{tabular}{|c|c|c|}
\hline $\begin{array}{l}\text { Social Values for Ecosystem Services } \\
\text { (SolVES) }\end{array}$ & $\begin{array}{l}\text { Mapping of societal values of ES } \\
\text { solves.cr.usgs.gov/ }\end{array}$ & ArcGIS required \\
\hline Envision & $\begin{array}{l}\text { Mapping of ES under scenarios } \\
\text { envision.bioe.orst.edu/ }\end{array}$ & No \\
\hline Ecosystem Portfolio Model (EPM) & $\begin{array}{l}\text { Mapping of ES under scenarios } \\
\text { geography.wr.usgs.gov/science/ sFloridaPM.html }\end{array}$ & No \\
\hline $\begin{array}{l}\text { (Ecological Asset Inventory and } \\
\text { Management) EcoAIM }\end{array}$ & Mapping of ES tradeoff & No information available \\
\hline ESValue & Mapping of ES production functions & No information available \\
\hline $\begin{array}{l}\text { Natural Assets Information System } \\
\text { (NAIS) }\end{array}$ & Mapping of ES values & No information available \\
\hline Ecosystem Valuation Toolkit & Mapping of ES values esvaluation.org/ & No \\
\hline WaterWorld & $\begin{array}{l}\text { Mapping of water-related ES under scenarios and } \\
\text { conservation priorities www.policysupport.org/ } \\
\text { waterworld }\end{array}$ & No \\
\hline Global Forest Watch Climate too & $\begin{array}{l}\text { Mapping of forest carbon ES values } \\
\text { climate.globalforestwatch.org/ }\end{array}$ & No \\
\hline $\begin{array}{l}\text { Wildlife Trade Tracker (TRAFFIC/ } \\
\text { WWF) }\end{array}$ & $\begin{array}{l}\text { Mapping of wildlife-trade ES flows } \\
\text { wildlifetradetracker.org/ }\end{array}$ & No information available \\
\hline \multicolumn{3}{|c|}{ Decision Support Tools around ES Mapping } \\
\hline SERVES & $\begin{array}{l}\text { Simple and Effective Resource for Valuing ES } \\
\text { esvaluation.org/about-serves/ }\end{array}$ & $\begin{array}{l}\text { Need to contact Earth } \\
\text { Economics to use it }\end{array}$ \\
\hline MESH & $\begin{array}{l}\text { Mapping Ecosystem Services to Human well- } \\
\text { being www.naturalcapitalproject.org/ MESH.html }\end{array}$ & Requires InVEST knowledge \\
\hline Maptionnaire & Participatory mapping portal maptionnaire.com & Not freely available \\
\hline MapNat Phone app & $\begin{array}{l}\text { Maps ES flows www.es-partnership.org/ } \\
\text { esp/83787/9/0/50 }\end{array}$ & $\begin{array}{l}\text { Available for Android phones } \\
\text { only }\end{array}$ \\
\hline MESP database & $\begin{array}{l}\text { Marine Ecosystem Services Partnership } \\
\text { marineecosystemservices.org/ explore }\end{array}$ & $\begin{array}{l}\text { Library of ES valuation } \\
\text { studies }\end{array}$ \\
\hline $\mathrm{BON}$ in a $\mathrm{BOX}$ & $\begin{array}{l}\text { Technology transfer for biodiversity observation } \\
\text { systems geobon.org/bon-in-a-box/whatis-bon-in-a- } \\
\text { box/ }\end{array}$ & Under development \\
\hline TESSA toolkit & Toolkit of ES site-based assessments tessa.tools/ & No \\
\hline $\begin{array}{l}\text { National Ecosystem Approach Toolkit } \\
\text { (NEAT) }\end{array}$ & $\begin{array}{l}\text { ES support for decision-making } \\
\text { neat.ecosystemsknowledge.net// }\end{array}$ & No \\
\hline ValuES & $\begin{array}{l}\text { Methods for integrating ES into policy, planning, } \\
\text { and practice aboutvalues.net/ }\end{array}$ & No \\
\hline ESP Visualisation Tool (ESP-VT) & $\begin{array}{l}\text { A data visualisation tool (Drakou et al., 2015) esp- } \\
\text { mapping.net/Home/ }\end{array}$ & No \\
\hline
\end{tabular}

\section{Challenges Related Ecosystem Services Mapping}

\subsection{The Main Challenge with Mapping Ecosystem Services}

Ecosystem services mapping is difficult and, as a new and developing science, there are variations in methods and typologies making projects challenging to compare and validate (Burgess et al. 2016). Studies vary in the different features of ES that are mapped (e.g. flow, supply, beneficiaries, demand, future situations, value) and the methods and information used (remote sensing in ArcGIS, to complex biophysical statistical models, to 
structured interviews). Differences in temporal and spatial scales and resolution as well as expectations behind data use, accuracy and accessibility make comparative studies hard and often inaccurate.

(Crossman et al. 2013) make the following recommendations for ecosystem services mapping:

1. Apply common indicator bundles to permit transferability and contrast.

2. Include all stakeholders at the very commencement of the developments.

3. Maps should match administrative boundaries for relevance but for geo-biophysical accuracy should be analysed at the river basin/watershed level.

4. Very varied ecosystem service landscapes (providers vs. beneficiaries) need more research.

5. It may not be essential to gather new data - utilize what is available.

6. Recognizing ecosystem services demand and supply hotspots (temporally and spatially) provides additional data.

7. Scenarios deliver useful context for future decision-making and policy setting

Besides, The main challenge in ecosystem management is the consideration of how multiple ES relate across various spatial scales and to provide management solutions that can manage ES synergies and trade-offs (Raudsepp-Hearne, Peterson, and Bennett 2010).

The synergies and trade-offs of ES are important to identify because they strengthen landscape flexibility (Qiu and Turner 2013) decrease prices to society and enhance societal welfare (Raudsepp-Hearne, Peterson, and Bennett 2010). geographic information systems (GIS) are a vital tool for ES analysis, because they permit to map of the ecological and human system limitations (Brevik et al. 2020).

ES valuations are challenged by multiple sources of uncertainty, (e.g. data scarcity, functional knowledge gaps, demand variability, community trade-offs, normative and value-laden arguments, (Dijk et al. 2018). This invokes direct dangers for decision making which is depend on ES-valuation (Hou et al. 2013).

The problem in ES research is the development of indicators for assessing and mapping ES, especially in geographic areas where data on biophysical, socio-cultural and economic activities are scarce (Dijk et al. 2018). A widely used method to overcome data scarcity is the use of expert knowledge (Depellegrin et al. 2016).

An associated problem is the resolution of the maps. Two things are problematic. The first is the more common query as to what quantity of detail is suitable for which decision-making level. Synergies among ecosystem services perceived at a watershed ruler may not reflect specific trade-offs observed at the native scale. Second, detailed maps are required for decision making particularly at the native and regional levels. Though, detailed data are frequently not presented, while processing and gathering them is costly. In addition to the general absence of data, one contributor raised the point that some ecosystem services are not spatial in nature and are therefore hard to map.

\subsection{Mapping to Decision-Making}

(Ruckelshaus et al. 2013) provided instances of the application of biodiversity and ecosystem service (BES) research into policy making and preparation processes at different locations across the world. They recommended various levels of effectiveness and explain the factors that allow higher levels of impact. They also highlighted how unsuccessful the transfer of BES data into decision-making has been, citing that the greatest impact is via those included in debates and participative procedures, and not directly into the policy itself, given a long time_scales frequently linked with policy change. (Willemen 2020) also noted the challenge 
of multiple and different methods to evaluate and map ES leading to limited mainstreaming of ES data into policy-making for guaranteeing that BES mapping is involved in decision-making:

1. Keep it easy for now - they require simple instruments with good records is more essential than compound models.

2. Include BES information as part of an iterative science-policy process - stressing the significance of contribution to build involvement and confidence.

3. Authorize local specialists to use information and tools as this facilitates improved buy in and uptake.

4. It is not always about the currency - value does not essentially have to be economic.

5. Relate ecosystem services and biodiversity change to human welfare.

6. Link the uncertainty in models.

\subsection{Political Challenges Posed by Mapping of Ecosystem Service}

The increase in the use of ES terminology and the idea of determining nature with regards to the value it brings to people is frequently greeted (Burgess et al. 2016) as it provides quantitative confirmation for the conserve or sustainable use of the environment. The skill to describe the value of nature with numbers, often commercial value, is attractive to policy makers as it is a physical calculate that can be applied for contrast with other forms of land or sea uses, such as profits from land protection to farming and houses.

Nevertheless, ES obtains criticism as it is realized by many as different from the traditional existence value rationale for environmental protection (Burgess et al. 2016). Fee schemes and monetary markets have also been criticized as part of a general capitalist growth into the natural sphere, creating markets out of nature and potentially exploiting poor societies who are not able to arrive at that market.

Therefore, the effort to map ES can be observed either positively by some collections of stakeholders and negatively by other groups. This must be kept in mind when any ES mapping is to be measured as the outcomes have several potential uses and some of these might be diverse to the estimation of those developing the maps.

\subsection{Challenges}

\subsubsection{Understanding anthropogenic ally modified systems (Challenge 1)}

For environmentalists working in such anthropogenic ally modified systems (e.g., agricultural landscapes, urban areas or forest production) challenges stand up in (i) the determination of human influence on serviceproviding units and related ecosystem services and (ii) considering the impact of landscapes nearby land units that provide ecosystem services.

Urban preparation that considers the fixing of green infrastructure in towns such as road trees and gardens may benefit biodiversity and many ecosystem services (e.g.,air filtration, water regulation, and noise decrease; (Bolund and Hunhammar 1999).Ecologists can directly donate to ecosystem service studies and help policy decisions, not only by estimating human impact, but also by suggesting anthropogenic interventions to benefit ecosystem services and service-providing units.

The development of places under human land use from a landscape perspective (e.g., agricultural fields, urban areas and pastures) at the price of losing (semi-)natural land) may lead to landscape fragmentation and simplification (Tscharntke et al. 2005).In farming landscapes, for example, arable fields deliver the final service of crop production, but constitute ephemeral and disturbed environments, while many species related with middle services (e.g., pollinators or biocontrol agents) based on less disturbed habitats in the around landscape (e.g., hedges or uncultivated field borders (Tsiafouli et al. 2015). 


\subsubsection{Evaluating ecosystem services (Challenge 2)}

Ecosystem services assessing tools, including mapping, quantification and modeling, are a problem of discussion in ecosystem service study (Sherrouse, Clement, and Semmens 2011). From the viewpoint of an ecologist challenges in evaluating ecosystem services arise from the necessity (i) to measure relationships among services and the kind of measures typically gathered in ecological studies (e.g., species richness) and (ii) to an explanation for the features of ecological processes (e.g., feedbacks, dynamics, and uncertainties) in numerical models focusing on service provision.

The valuation of biological control may consequently be developed if a small set of designated methods is included that covers features of service and disservice-providing units (e.g., pest consumption rates), ecosystem management (e.g., insecticide applications) and landscape modification (e.g., the quantity of semi-natural habitats in the nearby landscape). Consideration of abiotic variables such as climate (Michelotti, Machado, and Diehl 2013)or mud characteristics (Birkhofer et al. 2008) will add to the descriptive influence of this set of measures.

The quantification of uncertainty in estimate modeling needs critical assessment (Cheaib et al. 2012) and ecologists requirement to account for uncertainty particularly if (i) multiple capital donate to uncertainty (e.g., model and parameter uncertainty; (Barry and Elith 2006), (ii) uncertainties effect from mixtures of various sources (e.g., numerical associations and skilled knowledge; (Booth et al. n.d.) and (iii) new data requires an update of the models (e.g., in Bayesian frameworks (Ricketts et al. 2008).

Ecosystem services mapping is tense with multiple uncertainties stemming from uncertainty in the ability to capture related procedures as well as scaling and translating mapped data (Hou et al. 2013). The assessment of uncertainty, the integration of information about evolutionary aspects and human influences into the development of process-based models and their coupling with socioeconomic models are significant fields of future study to which environmentalists need to participate). (Keune et al. 2015).

\subsubsection{Analyzing relationships between ecosystem services (Challenge 3)}

Improving the understanding of the associations among ecosystem services poses two main challenges to environmental study: (i) drawing assumptions about associations among ecosystem services by understanding if associations are indirect through shared ecological drivers or direct because one ecosystem services causally impact another and (ii) solving problems of visualization and numerical testing when analyzing associations among multiple (more than two) ecosystem services. (Tsiafouli et al. 2015).

To research associations between two or three ecosystem services methods such as relationship analysis (Raudsepp-Hearne, Peterson, and Bennett 2010) or linear varied effect models (De Vries et al. 2013) can be applied. Efficiency frontier analyses (Nelson et al. 2008) or landscape optimization methods (Volk et al. 2010) are then often applied to find solutions for the simultaneous provision of services. It may be essential to consider multiple services in the same analytical outline, as it is likely that most services observed in a study are linked to each other.

For associating multiple services to drivers in a single analytical framework, the often use of principal element analysis is notable (Nemec and Raudsepp-Hearne 2013). The application of this technique should therefore be limit to datasets in which associations among multiple services are approximately linear (Greenleaf et al. 2016). Between the alternative approaches to visualize trade-offs among multiple services in one analytical framework, principal manages analysis holds potential as it permits for the analysis of non-linear relationships (Mooney 2005). Incomplete least squares regression is another promising method to analyze associations between middle ecosystem services depend on empirical information (Michael Haenlein 2004).

\subsubsection{Considering appropriate spatial and temporal scales (Challenge 4)}

A better understanding of the temporal and spatial scales at which the provision of ecosystem services is influenced by environmental change or anthropogenic interventions is required to satisfy the rising public and political request for sustainable land use (Kennedy et al. 2002). 
It is the main challenge for environmentalists to scale up from new plots to scales that are suitable for the management of most ecosystem services (Cardinale et al. 2012). These plot-degree studies can frequently not account for the heterogeneity of compound landscapes and hence may not offer adequate empirical information about provision ecosystem service from major land-use kinds in a landscape. Studies linking biodiversity to ecosystem services often focus on ecological procedures and middle ecosystem services at small spatial scales (Cardinale et al. 2012).

It is necessary to understand the time-based dynamics of service provision for the progress of conservation policies and sustainable management. For instance, the quality of provision of an ecosystem service may not only be based on its average provision over time, but also on its difference over time (Mori et al. 2013). So It is important to assess the steadiness of ecosystem service provision in easy ecosystems, where losses of ecosystem resilience to disturbances can be predictable to be strongest (Tscharntke et al. 2012). In addition, lag-effects of management decisions may make ecosystem service losses only apparent a long time after the anthropogenic involvement (Mooney 2005). Such lag-effects may be additionally emphasized by climate change, where the harm of biodiversity may decrease the flexibility of critical functions (Bengtsson et al. 2016).

long-term were needed to evaluations of provision ecosystem service to better know how inter-annual differences in ecological conditions, such as climate change, impact the magnitude and stability of service provision. Though, the timespan of environmental research is frequently constrained to a few years' duet generally short funding periods. Such short research periods will fail to provide reliable evaluations of altered behavior of service providing units in reply to climate change (Daily et al. 2009). The rare long-term studies, such as the Cedar Creek research in the US (Siemann et al. 1998) or the Biodiversity Examining in Germany (Fischer et al. 2010), deliver important insights into biodiversity and ecosystem operative over longer temporal scales.

\section{Conclusion}

Ecosystem services are the welfares of ecosystems to human well-being and the idea effectively bridges the divide between social and ecological systems and human get the benefits directly or indirectly from ecosystems and support human economy and well-being. The mapping of ecosystem services highlights the spatial associations among landscape features such as land use/cover, and their contribution to human welfare. The MES Appling public participatory GIS (PGIS) is a relatively new ground that provide a supplemental method to expert-driven ES mapping and modelling and refers to spatially explicit approaches and technologies for capturing and using spatial data in participatory planning procedures. ES maps are significant tools for decisionmakers and institutions, allowing them to spatially recognize which areas should be preserved due to their high supply of ES. Valuation of ES through benefit transfer used economic value to a land-cover map based on previous studies from sites having similar land cover types. GIS can be applied to visualize how ES is distributed across a landscape, to associate the distributions of multiple ES with drivers of change.

Though, challenges can increase when implementing such ES mapping effort to notify decision-making. ES mapping is challenging for number of causes. A key challenge in ecosystem management is the understanding of how multiple ES networks across different spatial scales and to provide management solutions that can manage ES trade-offs and synergies. Environmentalists must to adapt their viewpoint and approaches to a larger collective context for the enhancement of ES research. Particular emphasis requests to be directed toward help decision-makers with important data about service-providing units and mechanisms causal the provision of services at suitable temporal and spatial scales. To conclude, ES research is challenging for ecologists, but developing a multifaceted understanding of how the environment supports human welfare is crucial for the sustainable use of the ground's capital. ES research provides ecologists the single chance to act as developers for the understanding of how to conserve and sustain benefits gained from nature. 


\section{References}

Al-Quraishi, A., Razvanchy, H., \& Gaznayee, H. (2020). A Comparative Study for Performance of Five Landsat-based Vegetation Indices: Their Relations to Some Ecological and Terrain Variables. Journal of Geoinformatics \& Environmental Research 1(1): 20 - 37.

Bagstad, K. J., Villa, F., Batker, D., Harrison-Cox, J., Voigt, B., \& Johnson, G. W. (2014). From Theoretical to Actual Ecosystem Services: Mapping Beneficiaries and Spatial Flows in Ecosystem Service Assessments. Ecology and Society 19(2).

Bagstad, Kenneth J., Darius J. Semmens, Sissel Waage, and Robert Winthrop. (2013). A Comparative Assessment of DecisionSupport Tools for Ecosystem Services Quantification and Valuation. Ecosystem Services 5: $27-39$. http://dx.doi.org/10.1016/j.ecoser.2013.07.004.

Balzan, Mario V., Marion Potschin-Young, and Roy Haines-Young. (2018). Island Ecosystem Services: Insights from a Literature Review on Case-Study Island Ecosystem Services and Future Prospects. International Journal of Biodiversity Science, Ecosystem Services and Management 14(1): 71-90. https://doi.org/10.1080/21513732.2018.1439103.

Barry, Simon, and Jane Elith. (2006). Error and Uncertainty in Habitat Models. Journal of Applied Ecology 43(3): 413-23.

Bengtsson, J., Angelstam, P., Elmqvist, T., Emanuelsson, U., Folke, C., Ihse, M., Moberg, F. and Nyström, M. (2021). Reserves, resilience and dynamic landscapes 20 years later. Ambio, 50(5), 962-966.

Bicking, Sabine, Benjamin Burkhard, Marion Kruse, and Felix Müller. (2018). Mapping of Nutrient Regulating Ecosystem Service Supply and Demand on Different Scales in Schleswig-Holstein, Germany. One Ecosystem 3.

Birkhofer, K., Bezemer, T.M., Bloem, J., Bonkowski, M., Christensen, S., Dubois, D., Ekelund, F., Fließbach, A., Gunst, L., Hedlund, K. and Mäder, P. (2008). Long-Term Organic Farming Fosters below and Aboveground Biota: Implications for Soil Quality, Biological Control and Productivity. Soil Biology and Biochemistry 40(9): 2297-2308.

Bolund, Per, and Sven Hunhammar. (1999). Ecosystem Services in Urban Areas. Ecological Economics 29(2): $293-301$.

Booth, M. J., Branco, M. R., Ficz, G., Oxley, D., Krueger, F., Reik, W., \& Balasubramanian, S. (2012). Quantitative sequencing of 5-methylcytosine and 5-hydroxymethylcytosine at single-base resolution. Science, 336(6083), 934-937.

Brevik, E. C., Slaughter, L., Singh, B. R., Steffan, J. J., Collier, D., Barnhart, P., \& Pereira, P. (2020). Soil and Human Health: Current Status and Future Needs. Air, Soil and Water Research 13(2).

Burgess, Neil D, Sarah Darrah, Sarah Knight, and Fiona S Danks. (2016). Approaches To Mapping ECOSYSTEM SERVICES.

Cardinale, Bradley J et al. (2012). Citation for the Published Paper : Publishing Group . Epsilon Open Archive Http://Epsilon.Slu.Se Biodiversity Loss and Its Impact on Humanity. : 59-67.

Cash, D.W., Adger, W.N., Berkes, F., Garden, P., Lebel, L., Olsson, P., Pritchard, L. and Young, O. (2006). Scale and CrossScale Dynamics: Governance and Information in a Multilevel World. Ecology and Society 11(2).

Cheaib, A., Badeau, V., Boe, J., Chuine, I., Delire, C., Dufrêne, E., François, C., Gritti, E.S., Legay, M., Pagé, C. and Thuiller, W. (2012). Climate Change Impacts on Tree Ranges: Model Intercomparison Facilitates Understanding and Quantification of Uncertainty. Ecology Letters 15(6): 533-44.

Costanza, R., De Groot, R., Sutton, P., Van der Ploeg, S., Anderson, S.J., Kubiszewski, I., Farber, S. and Turner, R.K. (2014). Changes in the Global Value of Ecosystem Services. Global Environmental Change 26(1): 152-58. http://dx.doi.org/10.1016/j.gloenvcha.2014.04.002.

Crossman, N.D., Burkhard, B., Nedkov, S., Willemen, L., Petz, K., Palomo, I., Drakou, E.G., Martín-Lopez, B., McPhearson, T., Boyanova, K. and Alkemade, R. (2013). A Blueprint for Mapping and Modelling Ecosystem Services. Ecosystem Services 4: 4-14.

Daily, G.C., Polasky, S., Goldstein, J., Kareiva, P.M., Mooney, H.A., Pejchar, L., Ricketts, T.H., Salzman, J. and Shallenberger, R. (2009). Ecosystem Services in Decision Making: Time to Deliver. Frontiers in Ecology and the Environment 7(1): 2128 .

Depellegrin, Daniel, Paulo Pereira, Ieva Misiunė, and Lukas Egarter-Vigl. (2016). Mapping Ecosystem Services Potential in Lithuania. International Journal of Sustainable Development and World Ecology 23(5): 441-55.

Dijk, Van, Van Der Wal, J Tjalling, and García Blanco. (2018). Article ( Refereed ) - Postprint.

Fischer, M., Bossdorf, O., Gockel, S., Hänsel, F., Hemp, A., Hessenmöller, D., Korte, G., Nieschulze, J., Pfeiffer, S., Prati, D. and Renner, S. (2010). Implementing Large-Scale and Long-Term Functional Biodiversity Research: The Biodiversity Exploratories. Basic and Applied Ecology 11(6): 473-85.

Forrest, M. R. (1980). Scandinavian Audiology, Supplement The Efficiency of Hearing Protection to Impulse Noise.

Greenleaf, Sarah S et al. 2016. International Association for Ecology Bee Foraging Ranges and Their Relationship to Body Size Published by: Springer in Cooperation with International Association for Ecology Stable URL : Http://Www.Jstor.Org/Stable/40213008 REFERENCES Linked References . 153(3): 589-96.

Guerry, A.D., Ruckelshaus, M.H., Arkema, K.K., Bernhardt, J.R., Guannel, G., Kim, C.K., Marsik, M., Papenfus, M., Toft, J.E., Verutes, G. and Wood, S.A. (2012). Modeling Benefits from Nature: Using Ecosystem Services to Inform Coastal and Marine Spatial Planning. International Journal of Biodiversity Science, Ecosystem Services and Management 8(1-2): 107- 
21.

Gurnell, Angela M. (2016). River Science: Research and Management for the 21st Century Trees, Wood and River Morphodynamics: Results from 15 Years Research on the Tagliamento River, Italy.

Hassanpour, J., Mustafa, Y. T., \& Habeeb, H. N. (2018). Spatio-Temporal Estimation of Surface Water Area in Dohuk Governorate Using Remote Sensing \& GIS. In 2018 International Conference on Advanced Science and Engineering (ICOASE) (pp. 443-448). IEEE.

Hoffmann, A., Penner, J., Vohland, K., Cramer, W., Doubleday, R., Henle, K., Kõljalg, U., Kühn, I., Kunin, W.E., Negro, J.J. and Penev, L. (2014). Improved Access to Integrated Biodiversity Data for Science, Practice, and Policy - The European Biodiversity Observation Network (EU BON). Nature Conservation 6: 49-65.

Hou, D., He, H., Huang, P., Zhang, G. and Loaiciga, H. (2013). Detection of Water-Quality Contamination Events Based on Multi-Sensor Fusion Using an Extented Dempster-Shafer Method. Measurement Science and Technology 24(5).

Kennedy T. A; Naeem S., Howe K. M, Knops J. M. H., Tilman D., Reich P. B. (2002). Biodiversity as a Barrier to Glioma Cell Invasion Veel Moeten Veranderen o.a. Titel En Auteurs. Nature 417(June): 636-38.

Keune, H., Dendoncker, N., Popa, F., Sander, J., Kampelmann, S., Boeraeve, F., Dufrêne, M., Bauler, T., Casaer, J., Cerulus, T. and De Blust, G. (2015). Emerging Ecosystem Services Governance Issues in the Belgium Ecosystem Services Community of Practice. Ecosystem Services 16: 212-19. http://dx.doi.org/10.1016/j.ecoser.2015.06.001.

Lwin, Ko Ko, and Yuji Murayama. (2011). Web-Based GIS System for Real-Time Field Data Collection Using Personal Mobile Phone. Journal of Geographic Information System 03(04): 382-89.

Maes J, Fabrega Domenech N, Zulian G, Lopes Barbosa A, Vizcaino Martinez M, Ivits E, Polce C, Vandecasteele I, Mari Rivero I, Bastos De Morais Guerra C, Perpiña Castillo C, Vallecillo Rodriguez S, Baranzelli C, Ribeiro Barranco R, Batista E Silva F, Jacobs C, Trombetti M, Lavalle C. (2015). Mapping and Assessment of Ecosystems and Their Services Trends in Ecosystems and Ecosystem - JRC Report Number JRC94889. http://publications.jrc.ec.europa.eu/repository/handle/JRC94889.

Maes, Joachim, Benjamin Burkhard, and Davide Geneletti. (2018). Ecosystem Services Are Inclusive and Deliver Multiple Values. A Comment on the Concept of Nature's Contributions to People. One Ecosystem 3.

Mascia, M.B., Pailler, S., Thieme, M.L., Rowe, A., Bottrill, M.C., Danielsen, F., Geldmann, J., Naidoo, R., Pullin, A.S. and Burgess, N.D. (2014). Commonalities and Complementarities among Approaches to Conservation Monitoring and Evaluation. Biological Conservation 169: 258-67. http://dx.doi.org/10.1016/j.biocon.2013.11.017.

Michael Haenlein, Andreas M. Kaplan. (2004). A Beginner's Guide to Partial Least Squares Analysis, Understanding Statistics. Statistical Issues in Psychology and Social Sciences, Volume 3. Understanding Statistics 3(4): $283-97$. http://citeseerx.ist.psu.edu/viewdoc/summary;jsessionid=B982CC08B614550A8A5322631F1945CD?doi=10.1.1.461.8792.

Michelotti, Gregory A., Mariana V. Machado, and Anna Mae Diehl. (2013). NAFLD, NASH and Liver Cancer. Nature Reviews Gastroenterology and Hepatology 10(11): 656-65. http://dx.doi.org/10.1038/nrgastro.2013.183.

Mooney, Harold Alfred. 2005. AND HUMAN WELL-BEING.

Mori, K., Gotthelf, E.V., Zhang, S., An, H., Baganoff, F.K., Barriere, N.M., Beloborodov, A.M., Boggs, S.E., Christensen, F.E., Craig, W.W. and Dufour, F. (2013). Nustar Discovery of a 3.76 S Transient Magnetar near Sagittarius A. Astrophysical Journal Letters 770(2): 1-5.

Mzuri, R. T., Omar, A. A., Mustafa, Y. T. (2021). Spatiotemporal analysis of vegetation cover and its response to terrain and climate factors in Duhok Governorate, Kurdistan Region, Iraq. Iraqi Geological Journal, 54(1): 110-126.

Nelson, E., Polasky, S., Lewis, D.J., Plantinga, A.J., Lonsdorf, E., White, D., Bael, D. and Lawler, J.J. (2008). Efficiency of Incentives to Jointly Increase Carbon Sequestration and Species Conservation on a Landscape. Proceedings of the National Academy of Sciences of the United States of America 105(28): 9471-76.

Nelson, E., Mendoza, G., Regetz, J., Polasky, S., Tallis, H., Cameron, D., Chan, K.M., Daily, G.C., Goldstein, J., Kareiva, P.M. and Lonsdorf, E. (2009). Modeling Multiple Ecosystem Services, Biodiversity Conservation, Commodity Production, and Tradeoffs at Landscape Scales. Frontiers in Ecology and the Environment 7(1): 4-11.

Nemec, Kristine T., and Ciara Raudsepp-Hearne. (2013). The Use of Geographic Information Systems to Map and Assess Ecosystem Services. Biodiversity and Conservation 22(1): 1-15.

Obeyed M. H., Mustafa Y.T. and Akrawee Z. M. (2018). Estimating and Mapping Aboveground Biomass of Natural Quercus Aegilops Using WorldView-3 Imagery, 2018 International Conference on Advanced Science and Engineering (ICOASE), 2018, pp. 437-442, doi: 10.1109/ICOASE.2018.8548859.

Qiu, Jiangxiao, and Monica G. Turner. (2013). Spatial Interactions among Ecosystem Services in an Urbanizing Agricultural Watershed. Proceedings of the National Academy of Sciences of the United States of America 110(29): 12149-54.

Rabe, Sven Erik, Remo Gantenbein, Kai Florian Richter, and Adrienne Grêt-Regamey. (2018). Increasing the Credibility of Expert-Based Models with Preference Surveys - Mapping Recreation in the Riverine Zone. Ecosystem Services 31: 308-17.

Raudsepp-Hearne, C., G. D. Peterson, and E. M. Bennett. (2010). Ecosystem Service Bundles for Analyzing Tradeoffs in Diverse Landscapes. Proceedings of the National Academy of Sciences of the United States of America 107(11): 5242-47.

Ricketts, T.H., Regetz, J., Steffan - Dewenter, I., Cunningham, S.A., Kremen, C., Bogdanski, A., Gemmill - Herren, B., 
Greenleaf, S.S., Klein, A.M., Mayfield, M.M. and Morandin, L.A. (2008). Landscape Effects on Crop Pollination Services: Are There General Patterns? Ecology Letters 11(5): 499-515.

Roche, Stéphane. (2014). Geographic Information Science I: Why Does a Smart City Need to Be Spatially Enabled? Progress in Human Geography 38(5): 703-11.

Ruckelshaus, M., Doney, S.C., Galindo, H.M., Barry, J.P., Chan, F., Duffy, J.E., English, C.A., Gaines, S.D., Grebmeier, J.M., Hollowed, A.B. and Knowlton, N. (2013). Securing Ocean Benefits for Society in the Face of Climate Change. Marine Policy 40(1): 154-59. http://dx.doi.org/10.1016/j.marpol.2013.01.009.

Schaafsma, M., Morse-Jones, S., Posen, P., Swetnam, R.D., Balmford, A., Bateman, I.J., Burgess, N.D., Chamshama, S.A.O., Fisher, B., Green, R.E. and Hepelwa, A.S. (2012). Towards Transferable Functions for Extraction of Non-Timber Forest Products: A Case Study on Charcoal Production in Tanzania. Ecological Economics 80: 48-62. http://dx.doi.org/10.1016/j.ecolecon.2012.04.026.

Scholte, S.S., Daams, M., Farjon, H., Sijtsma, F.J., van Teeffelen, A.J. and Verburg, P.H. (2018). Mapping Recreation as an Ecosystem Service: Considering Scale, Interregional Differences and the Influence of Physical Attributes. Landscape and Urban Planning 175: 149-60. https://doi.org/10.1016/j.landurbplan.2018.03.011.

Sherrouse, Benson C., Jessica M. Clement, and Darius J. Semmens. (2011). A GIS Application for Assessing, Mapping, and Quantifying the Social Values of Ecosystem Services. Applied Geography 31(2): 748-60.

Siemann, Evan, David Tilman, John Haarstad, and Mark Ritchie. (1998). Experimental Tests of the Dependence of Arthropod Diversity on Plant Diversity. American Naturalist 152(5): 738-50.

Swetnam, R.D., Fisher, B., Mbilinyi, B.P., Munishi, P.K., Willcock, S., Ricketts, T., Mwakalila, S., Balmford, A., Burgess, N.D., Marshall, A.R. and Lewis, S.L. (2011). Mapping Socio-Economic Scenarios of Land Cover Change: A GIS Method to Enable Ecosystem Service Modelling. Journal of Environmental Management 92(3): 563-74.

Tscharntke, T., Klein, A.M., Kruess, A., Steffan - Dewenter, I. and Thies, C. (2005). Landscape Perspectives on Agricultural Intensification and Biodiversity - Ecosystem Service Management. Ecology Letters 8(8): 857-74.

Tscharntke, T., Tylianakis, J.M., Rand, T.A., Didham, R.K., Fahrig, L., Batáry, P., Bengtsson, J., Clough, Y., Crist, T.O., Dormann, C.F. and Ewers, R.M. (2012). Landscape Moderation of Biodiversity Patterns and Processes - Eight Hypotheses. Biological Reviews 87(3): 661-85.

Tsiafouli, M.A., Thébault, E., Sgardelis, S.P., De Ruiter, P.C., Van Der Putten, W.H., Birkhofer, K., Hemerik, L., De Vries, F.T., Bardgett, R.D., Brady, M.V. and Bjornlund, L. (2015). Intensive Agriculture Reduces Soil Biodiversity across Europe. Global Change Biology 21(2): 973-85.

Volk, M., Lautenbach, S., van Delden, H., Newham, L.T. and Seppelt, R. (2010). How Can We Make Progress with Decision Support Systems in Landscape and River Basin Management? Lessons Learned from a Comparative Analysis of Four Different Decision Support Systems. Environmental Management 46(6): 834-49.

De Vries, Sjerp, Sonja M.E. van Dillen, Peter P. Groenewegen, and Peter Spreeuwenberg. (2013). Streetscape Greenery and Health: Stress, Social Cohesion and Physical Activity as Mediators. Social Science and Medicine 94: $26-33$.

Willemen, Louise. (2020). It's about Time: Advancing Spatial Analyses of Ecosystem Services and Their Application. Ecosystem Services 44(February): 101125. https://doi.org/10.1016/j.ecoser.2020.101125. 